\title{
Effect of Education on Behavior About Head Liceon Students In East Jakarta
}

\author{
Salbiah Khamaruddin ${ }^{1}$, Warida Daulay ${ }^{2}$, Sri Sukamti ${ }^{3}$, and Suparni ${ }^{4}$ \\ ${ }^{1}$ Health Polytechnic of Jakarta III \\ Indonesia \\ Email: salbiah.khamaruddin80 [AT] gmail.com \\ ${ }^{2}$ Health Polytechnic of Jakarta III \\ Indonesia \\ Email: waridadaulay61 [AT] gmail.com \\ ${ }^{3}$ Health Polytechnic of Jakarta III \\ Indonesia \\ Email: sukamtisri [AT] yahoo.co.id \\ ${ }^{4}$ Health Polytechnic of Medan \\ Indonesia \\ Email: hajjahsuparni [AT] gmail.com \\ ${ }^{*}$ Corresponding author: Salbiah Khamaruddin
}

\begin{abstract}
Pediculosis Capitis is a skin and head hair infestation caused by Pediculus humanus var. capitis which belongs to the family Pediculidae. This parasite lives on the scalp, predilection mainly on the back of the head (occipital) and behind the ear (retroauricular). The eggs (nits) are attached to the base of the head hair shaft. Usually these parasites attack children and women with long hair. This parasite is an obligate parasite, meaning that it must suck human blood in order to maintain its life (Djuanda et al, 2013; Irianto, 2009). This study was to determine the effect of providing education on prevention and eradication of pediculosis capitis on changes in student behavior. The study was conducted at the Al Hamid Islamic boarding school in East Jakarta on 60 students infected with Pediculosis Capitis in March to August 2019. The type of research used was a quasi experiment with one group post-test and pre-test design to see whether or not the influence of education and treatment of behavior with the incidence of Pediculosis Capitis. Data analysis was performed by t-test which aims to analyze the differences in behavior before and after with a degree of significance (alpha) $=0.05$. The results showed that there were differences in the average value of behavior (knowledge, attitudes and actions) of students before and after the intervention of 3.33. There was a significant difference between students' behavior (knowledge, attitudes and actions) before and after the intervention with a $p$ value $<0.05$. It is recommended that routine checks (skrenning) of the presence of Pediculosis capitis occur in students living in the dormitory to prevent wider transmission.
\end{abstract}

Keywords---- Pediculosis capitis, education, behavior

\section{INTRODUCTION}

Pediculus humanus var. capitis atau yang biasa disebut dengan kutu kepala merupakan ektoparasit obligat yang mengandung darah pada manusia. In every phase of recycling is always related to humans, does not occur in animals, do not have wings and can not be bypassed. The spread of this parasite can be through direct transmission that is head contact with the head and indirect transmission through the use of items such as combs, hats, towels, pillows, mattresses and veils together.

Most head lice infestations occur in school-age children. Research conducted by Rassami and Soonwera in 2012 in Bangkok, Thailand stated that the ratio of Pediculus humanus infestation was var. capitis in schoolchildren in the 12-year age group the ratio is $26.07 \%$, while for the 8 -year-old age group the ratio increases to $55.89 \%$.

In Indonesia, according to research conducted by Aminah in 2015 stated that the incidence of Pediculus humanus var infestation. the capitis of students at Tarakanita Tritis Elementary School in Yogyakarta was $11.3 \%$ with a total of 62 research subjects. 
This disease has long been associated with poverty, a low economy and a run-down environment. This disease is often ignored because it is considered mild, especially in countries where there are other more serious health priorities. Nonetheless, this disease has caused significant morbidity among school children throughout the world.

Some factors that can help spread Pediculosis Capitis are socio-economic factors, poor level of knowledge, personal hygiene, residence density, and individual characteristics (sex, age, and hair length) (Hardiyanti et al, 2015).

Islamic boarding school is an educational institution with a boarding school system (joint education) so as to form a separate community whose members consist of students, teachers or religious teachers and family caregivers for the boarding school. Most pesantren in Indonesia have not received good attention, both from the owner, members of the pesantren community itself, and the government, both in terms of cleanliness, behavior, and concern for health (Hardiyanti et al, 2015). The same study was conducted in Medan in 2018 by Salbiah and received an infection rate in Medan in 2018 by Pediculosis Capitis in an Islamic boarding school at $80.3 \%$. The results obtained state that the use of a bed / pillow together, the use of a comb / hair accessories together and the length of the hair have a significant relationship with the incidence of Pediculosis Capitis (Salbiah, 2019).

During this time, techniques for controlling head lice still rely on the use of anti-flea insecticides. It is feared that overuse of insecticides can trigger head lice resistance against these insecticides. Chemicals that are often used to control head lice are chemicals including various synthetic insecticides that are nerve poisoning such as DDT, lindane, malathion, carbaryl, and permethrin (Burgess, 2004).

The formulation of the problem in this study is whether the provision of prevention education and eradication of Pediculosis capitis affect the change in behavior and the presence of Pediculosis capitis?

The purpose of this study was to determine the effect of pediculosis capitis education and treatment on student behavior and the presence of pediculosis capitis in Al Hamid Islamic boarding school in East Jakarta

\section{METHODS}

The study desain is a quasi experiment with one-group post-test and pre-test design to see whether or not the influence of education and treatment on behavior with the incidence of Pediculosis Capitis.

The study was conducted at Al Hamid Islamic Boarding School in East Jakarta in March to August 2019. The sample of the study was 60 people with positive criteria infected by Pediculus humanus var capitis.

Data analysis using t-test which aims to analyze the differences in behavior before and after the degree of significance with alpha $=0.05$ (95\% degree of confidence). The study was conducted at Al Hamid Islamic Boarding School in East Jakarta in March to August 2019. The sample of the study was 60 people with positive criteria infected by Pediculus humanus var capitis.

Data analysis using t-test which aims to analyze the differences in behavior before and after the degree of significance with alpha $=0.05$ (95\% degree of confidence).

\section{RESULTS}

Table 1: Overview of Pediculosis capitis in Students in Al-Hamid Islamic Boarding School East Jakarta

\begin{tabular}{|c|c|c|}
\hline Time of infection & Total (n) & Percent age (\%) \\
\hline Before entering to the hostel & 19 & 31 \\
\hline After entering to the hostel & 41 & 69 \\
\hline & 60 & 100 \\
\hline
\end{tabular}

From table 1 it can be seen that as many as 41 (69\%) students experienced Pediculosis capitis (head lice) infection after living in a dormitory and $19(31 \%)$ students were infected since before entering to the hostel.

Table 2: Description of actions in overcoming Pediculosis capitis (head louse) infection

\begin{tabular}{|l|c|c|}
\hline Infection prevention measures & Total (n) & Percent age (\%) \\
\hline Chemical medicine & 25 & 42 \\
\hline Cut hair & 43 & 77 \\
\hline & & \\
\hline
\end{tabular}


Table 2 shows that $35(58 \%)$ students had never used head lice to treat head lice infections and as many as 25 (42\%) used head lice. 43 (77\%) orangutans cut their hair to cope with head lice infection.

Table 3. Description of the use of sampho as an intervention per week

\begin{tabular}{|l|c|c|}
\hline Shampoo use & Total (n) & Percent age (\%) \\
\hline 3 times & 42 & 70 \\
\hline less than 3 times & 28 & 30 \\
\hline
\end{tabular}

Table 3 it can be seen that $42(70 \%)$ students use sampho which has been distributed three times and $28(30 \%)$ less than 3 times.

Table 4 The results of hair examination after the intervention

\begin{tabular}{|l|c|c|}
\hline The result & Total (n) & Percent age (\%) \\
\hline Negative & 40 & 67 \\
\hline Positive & 20 & 33 \\
\hline & & \\
\hline
\end{tabular}

From Table 4 it can be seen that 40 (67\%) negative for pediculosis capitis (head lice).

Based on table 7 it can be seen that the amount of data for groups of students before the intervention is 60 people and after the intervention is 60 people. The average value of knowledge before the intervention was 6.55 (not good) while the mean value after the intervention was 9.88 (good) with a difference of -3.333 . There is a difference in the average value of student knowledge before and after the intervention. From the table it can also be seen that the p-value $=0,000<0.05$ means that there are significant differences between the level of student knowledge before and after the intervention.

The average value of attitude before intervention is 6.47 (not good) while the average value for after intervention is 9.93 (good) with a difference of -3.467 . There are differences in the average value of student attitudes before and after the intervention. From the table it can also be seen that the $\mathrm{p}$-value $=0,000<0.05$, meaning that there is a significant difference between the level of student attitudes before and after the intervention.

The average value of the attitude before the intervention is 6.47 (not good) while the average value for after the intervention is 9.93 (good). There is a difference in the average value of student actions before and after the intervention with a difference of -3.467 . From the table it can also be seen that the p-value $=0,000<0.05$, meaning that there is a significant difference between the level of student action before and after the intervention.

\section{DISCUSSION}

Pediculosis capitis is a skin and head hair infestation caused by Pediculus humanus var. capitis which belongs to the family Pediculidae. This parasite lives on the scalp, predilection mainly on the back of the head (occipital) and behind the ear (retroauricular). The eggs are attached to the base of the head hair shaft. Usually these parasites attack children and women with long hair. This parasite is an obligate parasite, meaning that it must suck human blood in order to maintain its life (Djuanda et al, 2013; Irianto, 2009).

Cases of Pediculosis capitis (head lice) at Al Hamid Islamic Boarding School were mostly obtained by students after they entered to the hosstel. From the results of the study note that 41 (69\%) students got Pediculosis capitis (head lice) infection after living in the hostel and $19(31 \%)$ students were infected since before entering to the hostel. Students who suffer from head lice, there are those who were not initially infected with head lice and then contracted by other students while living in the cottage, and there are also students who have entered the cottage from the beginning of the head louse and then spread it to other students. Most cases of infection are caused by personal hygiene factors of students who are not good, such as rarely cleaning hair, borrowing and borrowing personal items, mattresses and pillows that are rarely dried in the sun, and sleeping habits together. The results of research in Banjarbaru by Rifqoh et al conclude that personal hygiene is associated with infection with Pediculosis capitis (head lice), (Rifqoh et al, 2017).

Pediculois infection in students who live in a dormitory is also influenced by many external factors such as the condition of the dormitory or cottage triggering students to do many things together, this can lead to an increased risk of transmitting fleas from people to others. When one member of a group or dormitory is exposed to pediculosis capcitis then other members will be at risk of being affected as well. Having knowledge and applying it well will help to intervene or treat pediculosis capitis. For example, by knowing the signs and symptoms of capitis pediculosis, when knowing one member of the group or boarding school is affected by pediculosis capitis then all other members must also be examined to detect early infections and treat them together. Individual treatment, will still have the risk of capitis pediculosis again 
if other members are still infected and not treated. From the results of the study note that $25(47 \%)$ students have taken treatment, but the effects of treatment are only temporary, because they are re-infected from students who are still infected.

Lack of students' knowledge about capiculosis pediculosis is because they have never done a health education about capiculosis pediculosis. Although students have good knowledge about pediculosis capitis, they cannot apply their knowledge about preventing and treating pediculosis capitis, but they will still be at risk of becoming infected. The same research results in 2017 in Banjarbaru show that there is a positive relationship between personal hygiene with moderate strength Pediculosis capitis Infestation (Rifqoh and Wardah. 2017).

Infected students experience disorders such as itching and scalp irritation due to scratching. This can have an impact on the disruption of student learning concentration and reduce the quality of sleep at night. Prolonged infection if not tested can cause anemia in children (Yousefi et al, 2012).

As many as $25(42 \%)$ students had never used lice medicine to deal with infections and $43(77 \%)$ students cut hair to treat lice infection. After counseling as many as $52(87 \%)$ students have good knowledge about pediculosis capitis (head lice) then $8(13 \%)$ students still have a poor level of knowledge then $55(92 \%)$ students have a good attitude and $5(8 \%)$ students have a bad attitude then $50(83 \%)$ students have good actions then $10(17 \%)$ were classified as having a bad behavior.

Most students who use sampho were distributed 3 times. Students who use sampho less than 3 times claim to discontinue use due to reasons for forgetting, until they run out and there are some of them complaining of itching after using sampho. The results of the evaluation of the effect of the use of sampho can be found that as many as 40 (67\%) students were negative for the presence of pediculosis capitis (head lice) and 20 (33\%) were still positive.

The average knowledge of students before the intervention was 6.55 (not good) while the average value after the intervention was 9.88 (good). Descriptive it can be said that there are differences in the average value of students' knowledge before and after the intervention.

One of the counseling topics given to students is about the frequency of washing hair. Washing your hair at least 3 times a week using sampho can reduce lice infection. In general, most students wash their hair three times a week after counseling. The results of the study by Esy Maryanti stated that the frequency of washing hair had no significant effect with the presence of Pediculosis capitis (Maryanti, 2018).

From the table it can also be seen that the value of Sig. (2-tailled) is $0.00<0.05$. This means that there are significant differences between students' behavior (knowledge, attitudes and actions) before and after the intervention. There is a significant (real) difference between the average behavior (knowledge, attitudes and actions) of students before and after education. These results are consistent with previous research in Yogyakarta which concluded that there is a relationship between the level of knowledge and the incidence of capiculosis pediculosis with an add ratio value of 0.281 (Aisy, 2018).

In Indonesia cases of Pediculosis capitis are still often found in the community. National figures for this case are not officially recorded, but from several studies in several areas, the infection rates are quite high. The results of the case study of Pediculosis capitis by Aprilia Zulinda et al in primary school students obtained an infection rate of 39.3\% (Zulinda et al, 2010). Some studies on Pediculosis capitis vary in the number of infections in this case. Research on Islamic boarding school students in Kutai Kartanegara district obtained an infection rate of 90.14\% (Zubaidah, 2018), 87.3\% in orphanage children in the city of Pekanbaru (Maryanti, 2018)), 19.87\% in elementary school students in The municipality of banjarbaru (Rifqoh, 2017), 58\% of foster children in the South Sumatra Dawah League orphanage (Anggraini, 2018).

\section{CONCLUSION}

As many as $40(67 \%)$ students were negative for pediculosis capitis (head lice) after the intervention. Most students have good behavior after the intervention with a level of knowledge $52(87 \%)$ students, attitudes $55(92 \%)$ students and actions $50(83 \%)$ students. There is a significant difference between the behavior (knowledge, attitudes and actions) of students before and after the intervention with a $\mathrm{p}$ value $<0.05$.

\section{RECOMENDATION}

a. The same study can be done in schools where students live together in dormitories to find out more about the epidemiology of Pediculosis capitis

b. It is necessary to have regular checks on the presence of Pediculosis capitis in students who live in the dormitory to prevent wider transmission. 
c. There needs to be a screening of the presence of Pediculosis capitis in new students who will enter the dormitory to prevent the entry of sources of transmission.

d. Regular use of serit combs and sampho specifically for head lice can reduce the presence of Pediculosis capitis.

e. Periodic personal hygiene education is needed to educate students to remind them of the importance of maintaining personal health.

\section{ACKNOWLEDGEMENT}

The author would like to thank the Poltekkes Kemenkes Jakarta III and Yayasan Pondok Pesantren Al-Hamid Jakarta and all individuals involved for their contribution and assistance in the data collection process.

\section{REFERENCES}

[1] Anggraini Annisa dkk, 2018. Hubungan Tingkat Pengetahuan dan Personal Hygiene terhadap kejadian Pedikuosis kapitis pada anak asuh di Panti Asuhan Liga Dakwah Sumatera Barat, Jurnal Kesehatan Andalas. Sumatera Barat. 7 (1)

[2] Centers for Disease Control and Prevention, 2013. Parasite Lice Head Lice, [online] Tersedia di: <https://www.cdc.gov/parasites/lice/head/index.html> [Diakses pada 17 Maret 2017]

[3] Djuanda, A., Hamzah, M., dan Aisah, S., 2013. Ilmu Penyakit Kulit dan Kelamin. Jakarta: Fakultas Kedokteran Universitas Indonesia.

[4] Maryanti Evy, dd, 2018. Hubungan faktor resiko dengan Infestasi P. Humanus capitis pada anak Panti Asuhan di kota Pekanbaru. Jurnal kesehatan Melayu, FK Unri. Vol 1 no 2: 73 - 79.

[5] Hardiyanti, N.I., dkk., 2015. Penatalaksanaan Pediculosis Capitis. Majority. 4(9): 47-52.

[6] Irianto, K., 2009. Parasitologi Berbagai Penyakit yang Mempengaruhi Kesehatan Manusia. Bandung: Yrama Widya.

[7 Notoatmodjo, S., 2012. Promosi Kesehatan dan Perilaku Kesehatan. Jakarta: Rineka Cipta.

[8] Nutanson, I., dkk., 2008. Pediculus Humanus Capitis: An Update. Acta Dermatoven APA. 17(4): 147-153.

[9] Rahman, Z.A., 2014. Faktor-Faktor yang Berhubungan dengan Kejadian Pediculosis Capitis pada Santri Pesantren Rhodlotul Quran Semarang. [Skripsi]. Semarang: Fakultas Kedokteran Universitas Diponegoro.

[10] Rassami, W., dan Soonwera, M., 2012. Epidemiology of Pediculosis Capitis Among Schoolchildren in the Eastern Area of Bangkok, Thailand. Asian Pac J Trop Biomed. 2(11): 901-904.

[12] Rifqoh dan Wahdah Norsiah, 2017. Pediculosis capitis dan Personal hygiene pada Anak Sd di daerah Peesaan Kotamadya Banjarbaru. Medial laboratory Technology Journal 3(2): 58 - 62

[13] Sembel, D.T., 2009. Entomologi Kedokteran. Yogyakarta: Penerbit Andi.

[14] Wawan, A., dan M., Dewi, 2011. Teori dan Pengukuran Pengetahuan, Sikap, dan Perilaku Manusia. Yogyakarta: Nuha Medika.

[15] Yousefi, S, Shampsiphoor F, Ahadi YS, 2012. Epidemiological Study of Head Louse (Pediculus humanus capitis) Infestasi among Primary school Students in Rural Area of Sirjan Country South of Iran Thrita J Med Sci.

[16] Zubaidah Mona dkk, 2018. Insidensi dan Gambaran Faktor Resiko Pedikulosis Kapitis di Pondok Pesantren X Kabupaten Kutai Kertanegara. Jurnal Kedokteran Mulawarman, (5/2):32 - 41

[17] Zulinda Aprilia dkk, 2000. Faktor-Faktor yang Mempengaruhi Kejadian Pedikulosis Kapitis pada Murid kelas III, IV, V dan VI SDN 019 Tebing Tinggi Okura Kecamatan Rumbai Pesisir Pekanbaru, Jurnal Ilmu Kedokteran, jilid 4 Nomor 1 : $65-69$. 